PAEDAGOGIA ChristianA

2/24 (2009) - ISSN 1505-6872

Marek Raszewski*

Włocławek

\title{
Edom jako instrumentum paedagogicum Boskiego Wychowawcy w Starym Testamencie
}

Autorzy biblijni - zarówno staro-, jak i nowotestamentowi - wielokrotnie ukazywali Boga jako Pedagoga - wielkiego wychowawcę Ludu Wybranego. Na kartach Pisma Świętego można znaleźć cały szereg bardzo bogatych w przesłanie pedagogiczne stwierdzeń czy obserwacji: „Szczęśliwy, kogo Bóg karci, więc nie odrzucaj nagan Wszechmocnego” (Hi 5, 17), „Bowiem karci Pan, kogo miłuje, jak ojciec syna, którego lubi” (Prz 3, 12), „Miłosierdzie człowieka - nad jego bliźnim, a miłosierdzie Pana - nad całą ludzkością: On karci, wychowuje, poucza i zawraca jak pasterz swoją trzodę” (Syr 18, 13), „Bo kogo miłuje Pan, tego karze, chłoszcze zaś każdego, którego za syna przyjmuje" (Hbr 12, 6). Autorzy biblijni, ukazując Boga jako Pedagoga, przytaczają różne przykłady. Największa Boża pedagogia objawiła się w drodze po pustyni, gdzie Bóg wychowywał, doświadczając i karząc, swój lud (por. Pwt 8$)^{1}$. Nierzadko też posługiwał się On obcymi narodami, które sam karał wobec Izraela, co miało być środkiem wychowawczym. Owe narody stawały się wówczas instrumentum paedagogicum w procesie wychowawczym Izraela. Na ich przykładzie Lud Wybrany mógł zaobserwować, co może się stać, gdy człowiek/ludzie są nieposłuszni Bogu². W niniejszym artykule nasza uwaga zostanie skupiona na fragmentach, w których pojawia się jeden z takich narodów. Jest nim Edom. Był to bratni naród Ludu Wybranego, gdyż

* Ks. dr Marek Raszewski, wykładowca egzegezy Nowego Testamentu i teologii biblijnej w Papieskim Wydziale Teologicznym w Warszawie, Oddział w Koninie.

${ }^{1}$ Por. F. Mickiewicz, Wychowawcze znaczenie pobytu Izraelitów na pustyni w świetle Pwt 8 , „Studia Theologica Varsaviensia” 31 (1993), s. 141-156; P. Bovati, Księga Powtórzonego Prawa (1-11), Kraków 1994, s. 113-130.

2 Por. M. Szmajdziński, Budowa i kompozycja literacka mów przeciwko narodom w Am 1, 3-2, 5, w: G. Pindur - P. Pindur (red.), ,Potrzeba, by On wzrastat, a ja się umniejszat” (J 3, 30). Księga pamiqtkowa ku czci śp. Księdza Profesora Józefa Homerskiego, Tarnów 2008, s. 196-197. 
jego protoplastą był Ezaw, brat Jakuba (Izraela), a równocześnie - zgodnie z żydowską tradycją - symbol odwiecznego wroga Izraela. Analiza mów prorockich przeciw Edomowi będzie miała na celu pokazanie, jak w Narodzie Wybranym odczytywano wydarzenia $\mathrm{z}$ historii Edomu i jakie wnioski wyciagano z niej dla własnych losów. W celu ukazania myśli pedagogicznej, jej bogactwa i rozwoju, prorockie wyrocznie przeciwko Edomowi zostaną ukazane w kontekście historii Ludu Wybranego, który zawsze znajdował się pod wpływem Bożej pedagogii. Prezentacja tych tekstów zostanie dokonana w ujęciu diachronicznym ${ }^{3}$. Pozwoli to uporządkować przywołane wyrocznie według kryterium czasowego. W porządku kanonicznym natomiast są to następujące teksty prorockie: Iz 21, 11-12; 34, 5-17; 63, 1-6; Jr 49, 7-22; Ez 25, 12-14; 35, 1-15; J1 4, 19b; Am 1, 11-12; Ab 1-21; Ml 1, 2-5.

Dokładne określenie choćby przybliżonych dat powstania poszczególnych ksiagg prorockich i znajdujących się tam wypowiedzi nie jest zadaniem łatwym. Większość z tych ksiag była wielokrotnie przeredagowywana i uzupełniana. Prorocy byli zasadniczo mężami słowa mówionego. Zadaniem proroka było przełożyć otrzymane od Boga posłannictwo na język ludzki, właściwy danej epoce i danemu środowisku słuchaczy. To Boże posłannictwo zostało utrwalone na piśmie - zostało spisane nie tylko z powodów religijnych, ale również wychowawczych dla dobra doczesnego i eschatologicznego Ludu Bożego 4 .

Działalność prorocka wchodziła w zakres publicznej funkcji religii. Przez proroctwo, rozwijające się na przestrzeni dziejów Ludu Wybranego, należy rozumieć nie tyle przepowiadanie przyszłości, ile raczej medytację i interpretację Bożej myśli przez proroka. Zastanawiając się nad istotą profetyzmu izraelskiego, szczególnie jeśli chodzi o wypowiedzi o Edomie, należy się mu przyjrzeć w kluczu chronologicznym. Poszczególne księgi powstały bowiem w odległej przeszłości, w warunkach społecznych, politycznych, kulturowych i religijnych, które były całkowicie odmienne od sytuacji, w jakiej my żyjemy. Te diametralnie różne warunki, zmieniające się w ciągu wieków, w czasie których narastał zbiór ksiag natchnionych, wyciskały swoje piętno na pisarstwie i sposobie wyrażania myśli przez autorów natchnionych.

Prorocy wypowiadający się o Edomie należą do proroków piszących oraz tych, których wyrocznie zostały spisane. Ten etap powstawania ksiag prorockich trwał aż do okresu późnego hellenizmu (II wiek przed Chrystusem). Księgi pro-

${ }^{3}$ Ujęcie diachroniczne (grec. dia - „przez” i chronos - „czas”) jest podejściem do tekstów biblijnych, próbującym rozpoznać, a następnie uporządkować je w sekwencji chronologicznej, a zatem tak jak one powstawały na przestrzeni czasu. Samo dojście do datacji mniejszych jednostek literackich w obrębie szerszego kontekstu (np. całej księgi) jest bardzo często niezwykle trudne i wymaga umiejętnego korzystania z metody historyczno-krytycznej. Uszeregowanie mniejszych jednostek literackich pozwala jednak prześledzić rozwój danej myśli w obrębie Starego lub Nowego Testamentu.

${ }^{4}$ Por. F. Fourier, Kim jest prorok?, „W drodze” 4 (1976), s. 36-47; L. R. Stachowiak, Prorocy - studzy stowa, Katowice 1980, s. 174-181. 
rockie traktujące o Edomitach zawierają wypowiedzi proroków, spisane przez nich samych, ich uczniów, albo pochodzą z przekazu tradycji. Prorocy pisali, aby wywrzeć większe wrażenie na narodzie (por. Jr 36), jak również, aby móc zweryfikować realizację tego, co powiedzieli. Dla większości związanych z Edomitami wypowiedzi można określić czas powstania ${ }^{5}$. W połowie VIII wieku przed Chrystusem prorocy, którzy wypowiadali się przeciwko Edomowi, to: Amos w Izraelu i ProtoIzajasz (Iz 1-39) w Judzie. Pod koniec VII wieku przed Chrystusem notuje się wystąpienia Jeremiasza, którego działalność sięgała początku następnego wieku. Przeżył on upadek Jerozolimy w 586 roku przed Chrystusem, później został uprowadzony do Egiptu i tam słuch o nim zaginął. Wśród wygnańców w Babilonii rozpoczął swą działalność Ezechiel, stając się z proroka gróźb prorokiem pocieszenia. Pod koniec niewoli babilońskiej wystapił prorok Abdiasz, którego słowa skierowane są prawie wyłącznie przeciwko Edomitom. W tym czasie powstała też większa część literatury pocieszającej, mającej podnieść na duchu Lud Wybrany po upadku Królestwa Judzkiego ${ }^{6}$. Po powrocie Izraelitów z niewoli, w epoce perskiej, odbudowie kraju, a przede wszystkim świątyni, towarzyszyły pouczenia proroka Joela i TritoIzajasza. TritoIzajasz (Iz 56-66), mówiąc o Edomie tłumaczył, dlaczego nie zrealizowały się jeszcze w pełni zapowiedzi jego mistrza DeuteroIzajasza. Przepowiedział on ich realizację na czasy mesjańskie. W V wieku przed Chrystusem prorokował Malachiasz. Po nieudanych próbach zbudowania królestwa ludzkim wysiłkiem przychodzi okres hellenizmu, w którym prorocy podkreślali bezpośrednią interwencję Boga.

Z przekonania o nieprzemijającej aktualności słów prorockich płyną bardzo poważne konsekwencje. Oryginalne słowo prorockie, przekazywane następnie ustnie czy na piśmie, było na nowo odczytywane w zmienionych okolicznościach historycznych i religijnych Ludu Wybranego. Słowo to jednak było często przystosowywane do nowych uwarunkowań za pomocą różnych objaśnień, uzupełnień, wstawek nowych tekstów lub przeróbek redakcyjnych, powstałych w nowych okolicznościach. Można jednak (w sposób nieco uproszczony, ,szkolny”) te księgi podzielić - przyjmując jako kryterium okres ich powstawania - na trzy grupy: księgi powstałe przed okresem niewoli babilońskiej, w czasie niewoli oraz te, które powstały po powrocie i po reformach Ezdrasza i Nehemiasza ${ }^{7}$.

\section{Okres przed niewolą}

Przed okresem niewoli babilońskiej głównym zadaniem proroków wypowiadających się przeciwko Edomowi było ostrzeganie przed skutkami odstępstwa od

${ }_{5}^{5}$ Por. B. Lang, Prophetic Call Traditions and Reports of Visions, „Zeitschrift für die Alttestamentliche Wissenschaft" 84 (1972), s. 123.

${ }^{6}$ Por. F. Fourier, dz. cyt., s. 42.

${ }^{7}$ Por. J. Warzecha, Historia Izraelitów, „Collectanea Theologica” 64 (1994), s. 39-45. 
zawartego przymierza oraz ukazywanie tego odstępstwa jako już obecnego faktu, a następnie nawoływanie do powrotu i skłonienia się do posłuszeństwa $\mathrm{Bogu}^{8}$. W połowie VIII wieku przed Chrystusem działali prorocy: Amos w państwie północnym i ProtoIzajasz w państwie południowym. Na atmosferę czasów, w których żyli i głosili Słowo Jahwe przeciwko Edomowi, miały wpływ długofalowe procesy polityczne, gospodarcze i religijne, sięgające swymi korzeniami czasów patriarchów, biegnące przez podział królestwa Salomona, aż do końca VIII wieku przed Chrystusem ${ }^{9}$.

Sytuacja polityczna Królestwa Północnego i Południowego była warunkowana sytuacją międzynarodową tego regionu, jak również wydarzeniami wewnętrznymi wynikającymi z podziału królestwa Salomona. Zjednoczone Królestwo było uważane za punkt kulminacyjny historii Ludu Wybranego jako państwa $^{10}$. W głębi kryło ono jednak silne napięcia natury politycznej, społecznej i religijnej, które dawały o sobie znać z coraz większym nasileniem po śmierci króla Salomona ${ }^{11}$. W konsekwencji nastapił upadek królestwa na skutek podziału na dwie niezależne jednostki państwowe: Królestwo Północne, zwane Izraelem, i Królestwo Południowe, zwane Judą ${ }^{12}$.

Wystapienie proroka Amosa i innych proroków przedwygnaniowych można datować na podstawie danych zawartych w jego Księdze (por. Am 1, 1; 7, 9. 10-17) na koniec pierwszej połowy VIII wieku przed Chrystusem. Mimo drobnych przesunięć czasowych jego działalności jest pewne, że prorokował, gdy królem w Izraelu był Jeroboam II (787/6-747/6 rok przed Chrystusem). Był on trzynastym królem Izraela po podziale monarchii Salomona w 932 roku przed Chrystusem, w tym czwartym w dynastii Jehu (843/2-747/6 rok przed Chrystusem). Była to najdłużej utrzymująca się przy władzy dynastia w Królestwie Północnym (prawie sto lat w ciagu dwóch wieków jego istnienia). Władcy jej wykazywali się odmiennymi zdolnościami w rządzeniu, a samo państwo przechodziło rozmaite koleje losu. Rządy Jeroboama II często porównuje się do świetności monarchii Ludu Wybranego za czasów Dawida i Salomona. Jego długie panowanie zostało w Starym Testamencie krótko przedstawione w 2 Krl 14, 23-29. Z tego zapisu dowiadujemy się, że przywrócił on granice Izraela „od wejścia do Chamat aż do Morza Araby”. Uzależnił także od siebie Damaszek i Chamat oraz Moab, Ammon i Edom.

W ślad za tymi wydarzeniami nastapiły przemiany społeczno-ekonomiczne. Społeczeństwo rozwijało się szybko i dynamicznie. Izrael zaczął liczyć się nie tylko politycznie na ówczesnej scenie międzynarodowej, ale także i ekonomicz-

${ }^{8}$ Por. C. Zaccagnini, La documentazione extrabiblica del tardo bronzo, „Reviev of Biblical Literature" 32 (1984), s. 1-27.

${ }^{9}$ Por. E. Vogt, Die Jahre der Könige von Juda und Israel, „Biblica” 45 (1964), s. 321-347.

${ }^{10}$ Por. G. Fohrer, Storia d' Israele, Brescia 1980, s. 141.

${ }^{11}$ Por. P. Hooker, A New Chronology for the Kings of Israel and Judah and its Implications for Biblical History and Literature, Atlanta 1988, s. 1-121.

${ }^{12}$ Por. S. Cohen, The Political Background of the Words of Amos, „Hebrew Union College Annual" 36 (1965), s. 153-160. 
nie. Rozwijał się handel, wzrastał dobrobyt mieszkańców, który osiągnął nawet poziom luksusu, zwłaszcza w stolicy Królestwa - Samarii. Znaleziono w niej np. dwieście tabliczek z kości słoniowej z rzadkimi ozdobami w złocie, które służyły jako ozdoba mebli w pałacu królewskim. Nastąpił rozwój i rozbudowa miast. Rolnictwo, a za nim środowisko wiejskie również uległy rozwinięciu. Przepychowi bogatych towarzyszyła nędza ubogich. Dawne stosunki równości, które panowały w relacjach wewnątrzspołecznych, rozpadają się i są zastępowane przez stosunki dominacji i wyzysku jednej grupy przez drugą. Bogaci wywodzą się głównie spośród znanych osobistości ${ }^{13}$. Ubodzy są jednostkami bezbronnymi. Takie złożone z różnych grup społeczeństwo odznaczało się niesprawiedliwością i jaskrawymi kontrastami pomiędzy bogatymi a ubogimi. Mali właściciele ziemscy, których status ekonomiczny był niewielki, znaleźli się w zależności od bogaczy ${ }^{14}$. Wraz z nadużyciami w życiu społecznym pojawił się upadek religijny. Ofiary składano w królewskim sanktuarium Betel oraz w Dan, Gilgal i Beer-Szebie. Nie zachowywano czystości obrzędów religijnych, a zdarzały się również, $\mathrm{i}$ to dość często, obrzędy wręcz niemoralne. Izraelici, podkreślając z mocą, iż są Ludem Wybranym, uważali, że można wejść w bezpośrednią relację z Bogiem za pomocą ofiar, darów, pielgrzymek i modlitw, a zatem poprzestać tylko na zewnętrznych przejawach religijności. Ponadto kult Jahwe zaczął być powoli wypierany przez kult Baala.

Pomyślność w życiu politycznym i społecznym w Królestwie Północnym miała zatem w gruncie rzeczy bardzo słabe podstawy. Jeżeli spojrzy się szerzej na ogólne uwarunkowania polityczne, nietrudno zauważyć, że opierała się w zasadzie na ekspansji potęgi asyryjskiej w kierunku Syrii, a w konsekwencji na słabości Damaszku, co skutkowało stabilizacją polityczną Izraela. Wyrazem napięcia w Izraelu, wywołanego podziałem społeczeństwa, może być właśnie wystąpienie proroka Amosa. Po śmierci Jeroboama II Królestwo Północne szybko zaczęło tracić swoje znaczenie polityczne, aż doszło do jego ostatecznego upadku w wyniku najazdu Sargona II, który zdobył Samarię w 721 roku przed Chrystusem. Po jej upadku nastapiła deportacja znacznej części ludności izraelskiej do Asyrii i Medii (por. $2 \mathrm{Krl} \mathrm{17,5-6),} \mathrm{a} \mathrm{na} \mathrm{miejsce} \mathrm{deportowanych} \mathrm{zostali} \mathrm{sprowadzeni} \mathrm{prze-}$ siedleńcy z Babilonu. W ten sposób doszło do wymieszania się resztek ludności izraelskiej z najniższych warstw społecznych z obcymi przybyszami, w wyniku czego powstał bardzo niejednolity lud zwany Samarytanami, który ze względu na nieczystość rasy był znienawidzony przez Judejczyków, jak również później przez Żydów po ich powrocie z niewoli babilońskiej ${ }^{15}$. Upadek Samarii oznaczał koniec tragicznej historii Królestwa Północnego ${ }^{16}$. Zapewne jego mieszkańcy

${ }^{13}$ Por. E. Vogt, dz. cyt., s. 321-347.

${ }^{14}$ Por. G. Witaszek, Amos. Prorok sprawiedliwości społecznej, Lublin 1996, s. 42.

${ }^{15}$ Por. E. Vogt, dz. cyt., s. 321-347.

${ }^{16}$ Por. T. Brzegowy, Ostatnie dziesięciolecia Królestwa Judzkiego, „Roczniki Teologiczno-Kanoniczne KUL" 47 (2000), s. 39-61. 
mieli świadomość, iż w ten sposób wypełniły się proroctwa Amosa, mówiące o zamienieniu świąt w żałobę, a pieśni w lamentacje (por. Tb 2, 6 z Am 8, 10) oraz spustoszeniu i zniszczeniu Izraela, jego świątyń i dworu królewskiego (por. Am 7, 9), gdy nadejdzie „dzień Jahwe” (hebr. jôm jhwh; por. Am 5, 18-20).

W swoich wypowiedziach o Edomie prorocy przedwygnaniowi często zapowiadali karę i sąd Jahwe. ProtoIzajasz (por. Iz 11, 14), mówiąc o Edomie, akcentował przyszłą odbudowę Izraela. Odnowiony i ponownie zjednoczony Izrael rozciagnie swój autorytet na otaczające państwa tak, że nie będzie musiał już nigdy więcej żyć w strachu. Izajasz miał dostęp zarówno do króla, jak i do wyższych kręgów urzędniczych (por. Iz 7, 3; 8, 2; 22, 15nn) oraz znał dobrze stosunki polityczne, społeczne i kulturowe stolicy, być może był szlachetnego pochodzenia i został wychowany w Jerozolimie. W ten sposób można wytłumaczyć zadziwiającą bliskość Izajasza z tradycją sapiencjalną (por. Iz 1, 2; 11, 2; 10, 15) ${ }^{17}$.

Rozdział 11 Księgi Izajasza opisuje sytuację podobną do okresu, w którym panował król Dawid, kiedy to kraje ościenne były mu poddane. W niniejszym fragmencie naród edomicki nie posiada jakiegoś specjalnego znaczenia - jest jednym z wielu wymienionych narodów, które znajdą się pod panowaniem Izraela ${ }^{18}$. Natomiast w Iz 21, 11-12 zawarta jest krótka wyrocznia dotycząca narodu, który został określony mianem dûmâ. W całej mowie są wymienione: Babilon, Filistea, Moab, Damaszek, Egipt, Babilon, Duma, Arabia, Juda oraz Tyr. Należy jednak zwrócić uwagę, że wyrocznia ta rozpoczyna się odniesieniem do góry Seir, która jednoznacznie przywodzi na myśl Edom. Chociaż ogólnie treść wyroczni jest enigmatyczna, to jednak sens wydaje się jasny - prorok nie oznajmiał Edomowi pocieszenia. Należy zwrócić uwagę, że Iz 21, 11 n ani nie oskarża narodu edomickiego za jakieś zbrodnie, ani nie przypisuje mu specjalnej roli. Edom jest tu po prostu wymieniony jako jeden spośród narodów ${ }^{19}$.

Następna wyrocznia proroka ProtoIzajasza z okresu przedwygnaniowego (34, 1-17) skierowana jest do narodów obcych. Wyrocznia ta ukazuje sąd nad Edomem jako złożenie ofiary przy użyciu miecza Jahwe zstępującego z niebios (ww. 5n). W dalszej kolejności (ww. 9-17) opisane są następstwa sądu, według którego terytoria Edomu staną się wiecznymi nieużytkami zamieszkałymi tylko przez pustynne zwierzęta. Obrazy te przywodzą na myśl opisy zniszczeń Sodomy i Gomory (por. Jr 49, 18) ${ }^{20}$. W takim ujęciu Edom może być ostatnim spośród

${ }^{17}$ Por. M. Gołębiewski, Kult i sprawiedliwość wedtug Izajasza, w: G. Witaszek, A. Paciorek, A. Kiejza (red.), Wszystko czynię dla Ewangelii. Księga Pamiatkowa ku czci O. Prof. Hugolina Langkammera OFM, Lublin 2000, s. 99-106.

${ }^{18}$ Por. G. Davies, The Destiny of the Nations in the Book of Isaiah, w: J. Vermeylen (red.), The Book of Isaiah, Leuven 1989, s. 97n.

${ }^{19}$ Por. P. Lohmann, Das Wächterlied Jes 21,11-12, „Zeitschrift für die Alttestamentliche Wissenschaft” 33 (1913), s. 20-29; J. Geyer, The Night of Dumah (Isaiah XXI 11-12), „Vetus Testamentum" 42 (1992), s. 317-339.

${ }^{20}$ Por. C. Mathews, Defending Zion: Edom's Desolation and Jacob's Restorian (Isaiah 34-35) in Context, Yale University 1994, s. 101-122. 
narodów, które dosięgnie Boża kara. W wyroczni ProtoIzajasza (Iz 34, 1-17) brakuje w szczególności konkretnych zarzutów przeciw Edomowi za jego zbrodnie. Akt oskarżenia jest także dość ogólną wypowiedzią (w. 8). Ogłasza ona odpłatę, rozumianą jako karę Jahwe za przewinienia wobec Syjonu. Należy jednak w tym miejscu zaznaczyć, że Księga Izajasza nigdzie nie przypisuje Edomowi wrogiego nastawienia względem Syjonu. Ogólny charakter wypowiedzi wskazuje, że Edom jest w tym przypadku reprezentantem wszystkich narodów. Wyrocznia ta otrzymuje swoje wyjaśnienie w następnym rozdziale (zob. zwł. Iz 35, 4). Miecz Jahwe dokona pomsty na narodach za to, że okupowały Syjon albo utrudniały wygnańcom powrót do Jerozolimy ${ }^{21}$.

W Iz 34 nazwa „Edom” odnosi się do konkretnego narodu i miejsca wraz z jego głównym miastem - Bosrą jednak funkcjonuje ona także - jak zostało to wcześniej zaznaczone - jako ilustracja czy typ wszystkich narodów. Nasuwa się pytanie dlaczego Edomowi została nadana taka rola? W kontekście jednak całej Księgi Izajasza, w której zauważalny jest brak wyraźnych zarzutów przeciw Edomowi, próby jedynie historycznego wythumaczenia negatywnego obrazu tego narodu pozostają niewystarczające. W wyjaśnieniu należy zwrócić uwagę, że początkowe wersety Iz 34 łączą Edom z innymi narodami bardziej przez skoncentrowanie się na podobieństwie ich losów, niż na szczegółowym wymienianiu ich czynów. Edom jest więc raczej symbolem, którego nazwa i położenie geograficzne przywodzą na myśl nie tylko jego własny los, ale także los innych obcych narodów ${ }^{22}$.

Jeśli chodzi o umiejscowienie Jeremiasza i jego wyroczni o Edomie, to umieściliśmy je w okresie przedwygnaniowym. Księga Jeremiasza przysparza rzeczywiście wiele trudnych redakcyjno-historycznych problemów. Obejmuje ona, po pierwsze - analogicznie do przepowiadania wcześniejszych proroków w VIII wieku przed Chrystusem - słowa ułożone metrycznie, o charakterze poetyckim; po drugie, mowy pisane prozą o charakterze kaznodziejskim. Podczas gdy przeciwnicy Jeremiasza przeczą jego zapowiedzi zbliżającego się nieszczęścia (por. Jr 23, 17; 28, 2), on sam podaje w wątpliwość ich posłannictwo (por. Jr 23, 21). W słowie Jeremiasza skierowanym przeciw Edomitom pobrzmiewa rozmowa z Bogiem wyrażona w formie skargi. Oskarżenie i zapowiedź sądu mogą zostać wypowiedziane u Jeremiasza jako skarga. Jeremiasz, jak i jego przeciwnicy ( Jr 23, 29; 5, 14) odczuwali słowo jako „ogień płonący” (Jr 20, 9). Prorok Jeremiasz w krótkiej wyroczni (por. Jr 9, 24-25) przedstawia Boską mowę, w której Jahwe ogłasza, że będzie karał okoliczne narody zamieszkujące: Egipt, Judę, Edom, Ammon, Moab i Arabię, określoną tutaj jako kraj plemion żyjących na pustyni ${ }^{23}$.

${ }^{21}$ Por. M. Pope, Isaiah 34 in Relation to Isaiah 35,40-60, „Journal of Biblical Literature” 71 (1952), s. 235-243.

${ }^{22}$ Por. J. Muilenburg, The Literary Character of Isaiah 34, „Journal of Biblical Literature” 59 (1940), s. 339-340.

${ }^{23}$ Istotą proroctwa jest wieść o nadchodzącym sądzie: nie ma sensu powtarzanie Bożych obietnic o pomocy, jeśli lud nadal trwa w grzechu i bałwochwalstwie. Jeremiasz mówił stale o grożącym upadku Jerozolimy. Lecz jest także nadzieja na przyszłość w powrocie z wygnania i w no- 
Ważnym stwierdzeniem jest tutaj, że Juda i Izrael - jako narody Przymierza, którego znakiem miało być obrzezanie - są postawione pod Boży sąd razem z innymi narodami. Sam natomiast Edom jest tutaj wspomniany jako jeden z narodów, bez szczegółowych określeń ${ }^{24}$.

W następnej swojej wypowiedzi Jeremiasz (por. Jr 25, 15-29) przedstawia kielich gniewu Jahwe, który został skierowany za pośrednictwem proroka na różne narody z przeznaczeniem, aby z niego piły. Jest to obraz kary Bożej. Edom jest wymieniony pośród bardzo wielu narodów, ale nie pełni jakiejś szczególnej funkcji. Natomiast fragment Jr 27, 1-22 opisuje w narratywnej formie odpowiedź Jeremiasza udzieloną zgromadzeniu obcych wysłanników zebranych wokół Jerozolimy około 594/3 roku przed Chrystusem w celu zawiązania i umocnienia kolacji antybabilońskiej. Owi wysłannicy reprezentowali królów Edomu, Moabu, Ammonu, Tyru i Sydonu. Jeremiasz ostrzegał przed koalicją oraz zachęcał, aby poddać się królowi babilońskiemu ${ }^{25}$. Jahwe bowiem zezwoli narodowi, który się podda, aby dalej zamieszkiwał w swojej ziemi. Jeżeli jednak Jerozolima odmówi kapitulacji, to zostanie zniszczona przez Nabuchodonozora. Edom wymieniony jest $\mathrm{w}$ tym rozdziale jako jeden $\mathrm{z}$ adresatów mowy proroka. Wyrocznia Jr 49, 7-22 przeciwko Edomowi stanowi piątą wypowiedź proroka pośród kolekcji ośmiu mów przeciwko obcym narodom w Jr 46-51. Siedem mniejszych narodów zostało wspomniane przed adresatem najdłuższej mowy, czyli Babilonem: Egipt, Filistea, Moab, Ammon, Edom, Damaszek oraz Kedar i Chazor (jedna wyrocznia). W tej perykopie z okresu przedwygnaniowego brak jakiegoś wyraźnego oskarżenia Edomu za zbrodnie popełnione w przeszłości. Są natomiast ukazane różne obrazy zniszczenia, które mają dotknąć ten naród. Podobnie jak w przypadku wspomnianych siedmiu wyroczni, Edom także nie odgrywa w tym tekście szczególnej reprezentacyjnej roli. Jest on po prostu jednym z narodów, które mają zostać osądzone przez Jahwe. Można jednak przypisać Edomowi pewną symboliczną rolę w Jr 49, 7-22. Zachodzi bowiem pewne podobieństwo pomiędzy wyrocznią o Edomie a wyroczniami o Babilonie (por. Jr 50, 1-51. 64). To sugeruje, że można w kolekcji Jr 47-51 powiązać Edom z Babilonem. W związku z tym Edom - podobnie jak Babilon - może reprezentować wszystkie narody, a zwłaszcza te, które są przeciwnikami Ludu Wybranego.

Symbolika i odniesienia do Sodomy i Gomory oraz Jordanu użyte w Jr 49, 18-21 o wiele bardziej łączą się z Edomem niż z Babilonem (por. Jr 50, 40. 44-46). Prorok, odnosząc część analizowanej wcześniej wyroczni do wielkiej mowy przeciwko Babilonowi, sprowadza właśnie ten ostatni naród do poziomu innych.

wym przymierzu, które Bóg zapisze w sercach i umysłach swego ludu. Bardziej niż jakikolwiek inny prorok, Jeremiasz zajmuje się osobistą wiarą i pokutą. Osobowość Jeremiasza ukazuje się bardzo wyraźnie w jego modlitwach; osobowość innych proroków nie została ukazana tak dobrze. Por. E. Vogt, dz. cyt., s. 321-347.

${ }^{24}$ Por. tamże, s. 323.

${ }^{25}$ Por. J. Muilenburg, dz. cyt., s. 337. 
Wówczas jest on przeznaczony do otrzymania tej samej kary, co pozostałe narody. Wyrocznia Jr 49, 7-22 ukazuje Edom jako jeden spośród wielu narodów, które są przeznaczone na Boży sąd. Naród ten nie wyróżnia się tutaj bardziej znaczącą rolą czy reprezentacyjnymi cechami od innych. Jedyną cechą charakterystyczną tej jednostki jest wspomnienie postaci Ezawa, który przywodzi na myśl jego relacje z Jakubem.

Jednak temat ten nie jest tak mocno rozwinięty jak na przykład w Księdze Abdiasza, który działał $\mathrm{w}$ okresie niewoli babilońskiej. Jeremiasz obiecywał w swoich wypowiedziach pochodzących już prawdopodobnie z okresu niewoli dla Królestwa Północnego szczęście tym, którzy doznali nieszczęścia. Podobnie zapowiadał on Judzie/Jerozolimie pokój wyłącznie po odbyciu sądu. Jahwe spogląda przyjaźnie nie na tych, którzy pozostali w Jerozolimie, lecz na tych, którzy zostali deportowani do Babilonii. Będą oni jednak musieli przebywać na wygnaniu dwa do trzech pokoleń, około siedemdziesięciu lat. Jeremiasz wzywał ich, by się na to przygotowali i by modlili się o powodzenie obcej potęgi. Mesjańska przepowiednia o „sprawiedliwej odrośli” (Jr 23, 5n) pozostaje w stosunku do tego - ale także w porównaniu z obietnicami Księgi Jeremiasza, na których się opiera - raczej lamentacją. Słowo o „nowym przymierzu” (Jr 31, 31nn.; 32, 27nn), które ma tak istotne oddziaływanie, nie pochodzi raczej od samego Jeremiasza, jednak odzwierciedla dogłębnie prorockie przepowiednie w kontekście pomiędzy złamaniem przymierza, zawinionym przez Izrael, a jego nowym ustanowieniem przez samego Jahwe. Jahwe będzie Bogiem Izraela, a Edom będzie pod jego panowaniem. To Bóg umieści w ludzkim sercu swoją wolę i tak umożliwi dobrowolne posłuszeństwo, a przez to Boże panowanie nad wszystkimi narodami ${ }^{26}$.

\section{Okres niewoli}

Babilonia istniała niespełna sto lat (625-538 przed Chrystusem) jako mocarstwo, które było śmiertelnym zagrożeniem dla Królestwa Południowego. W latach 587-586 przed Chrystusem Babilonia zdołała zniszczyć jego państwowość, dokonać rzezi Jerozolimy oraz zbezcześcić i zburzyć największą świętość ludu Bożego, jaką była Świątynia. W celu utrzymania podbitego narodu w ryzach państwo babilońskie prowadziło politykę niszczenia jego tożsamości: w trzech kolejnych deportacjach (około 597, 586 i 581 roku przed Chrystusem) uprowadzono z Judei wiele tysięcy ludzi i w ten sposób pozbawiono kraj całej jego elity kulturalnej i gospodarczej. Izraelici, zabrani do niewoli babilońskiej, wykorzenieni z ziemi ojczystej i pozbawieni tradycyjnych instytucji religijnych, poddani byli nieuchronnym procesom wynarodowienia, co w tamtych czasach

${ }^{26}$ Por. E. Vogt, dz. cyt., s. 337. 
oznaczało również odejście od Boga prawdziwego i przyjęcie kultów bałwochwalczych $^{27}$.

Właśnie w czasach niewoli babilońskiej zdarzył się ów niezwykły, pierwszy w ludzkich dziejach przypadek. Lud Wybrany utracił swoją suwerenność i zrobiono wszystko, żeby rozpłynął się w masie innych narodów. A jednak naród ten nie tylko nie porzucił swojej religii na rzecz religii zwycięzców, ale jeszcze się w niej oczyścił i pogłębił. Tu objawia się pedagogiczny wymiar wygnania jako kary. Jedynym i niepowtarzalnym doświadczeniem, rejestrującym kompleksowe przeżycie klęski, było doświadczenie wieku VI przed Chrystusem, określanego okresem niewoli babilońskiej. Naród Izraela, a zarazem i państwo przestały istnieć. Okupant zniszczył Jerozolimę i wiele innych miast. Świątynia ograbiona i spalona przestała istnieć. Zaginęły również znaki mówiące o obecności Boga, zwłaszcza Arka Przymierza. Olbrzymia większość ludności, włącznie z dynastią Dawida, została deportowana. Mędrcy Izraela stawiali sobie pytanie, dlaczego Bóg Przymierza do tego dopuścił? Poszukując rzetelnej odpowiedzi, z własnej woli, a także za natchnieniem Jahwe, zrozumieli najpierw to, co jest historyczne i swoją własną winę. Będąc niewiernymi Przymierzu, posunęli się za daleko, gdy chcieli odebrać Bogu inicjatywę zbawczą i przejąć ją w swe ręce ${ }^{28}$. Prorocy, także współczesny im Jeremiasz, powtarzali nieustannie, że to Bóg jest wybawicielem, jeśli się Jemu zaufa. Ale przyszła także i pogłębiona refleksja, wskazująca, że lud ten mimo niewoli nie przestał być ludem Pana, a Przymierze jest nadal aktualne (Ezechiel). Wreszcie uświadomili sobie, iż Bóg prowadzi ich w kierunku królestwa Ducha, które na pewnym etapie jest związane ze strukturami instytucjonalnymi i ziemskimi, by ostatecznie przejść w królestwo eschatologiczne, wolne od wszelkich struktur doczesnych.

Podczas niewoli babilońskiej prorocy (szczególnie Abdiasz i Ezechiel) wyjaśniali sens historii. Tłumaczyli, w jaki sposób wydarzenia niewoli mieściły się w Bożym planie dla Izraela, zapowiadali też jego odnowę. Wystąpienia proroków nie były osądzaniem z zewnątrz, lecz stanowiły refleksję nad wydarzeniami, które były czymś złym również dla proroków. Były też próbą zobaczenia dobrych skutków, jakie mogły one przynieść ${ }^{29}$. Prorocy w tym czasie wytrwale głosili trzy prawdy ${ }^{30}$. Po pierwsze: klęska i niewola spotkała Lud Wybrany nie dlatego, żeby Bogu zabrakło sił do jego obrony; po drugie, doprowadziły go do tego jego własne grzechy; po trzecie, Bóg w swoim miłosierdziu sprawi, że właśnie przez tę niewolę dokona się oczyszczenie Izraela i jego powrót do Boga ${ }^{31}$.

${ }^{27}$ Por. T. Matras, Wpływ niewoli babilońskiej na życie religijne Izraelitów, „Częstochowskie Studia Teologiczne" 3 (1975), s. 321-341.

${ }^{28}$ Por. S. Strus, Duchowy tragizm Jeremiasza, „Ruch Biblijny i Liturgiczny” 2 (1949), s. $81-83$.

${ }^{29}$ Por. E. Vogt, dz. cyt., s. 321-347.

${ }^{30}$ Por. S. Potocki, Złość grzechu w nauce proroków sprzed niewoli babilońskiej, „Roczniki Teologiczno-Kanoniczne KUL" 9 (1962), s. 81-97.

${ }^{31}$ Por. E. Vogt, dz. cyt., s. 321-347. 
Proroctwo Abdiasza jest najkrótszą księgą Starego Testamentu, zawierającą zaledwie dwadzieścia jeden wersetów, i jest ono skierowane przeciwko Edomitom, potomkom Ezawa. Nic nie wiemy o życiu i działalności proroka głoszącego mowy i o autorze księgi oprócz jego imienia, które w języku hebrajskim oznacza „sługa Jahwe”. W związku z tym są trudności w ustaleniu daty powstania tej księgi. Umieściliśmy ją we wcześniejszej prezentacji w okresie wygnania, ponieważ tak ostra krytyka Edomu za jego przewinienia wobec Izraela najprawdopodobniej mogła powstać w okresie największego kryzysu, tj. niewoli babilońskiej. Poważnym problemem literackim w Księdze Abdiasza jest wyraźny paralelizm między Ab 1-6 a Jr 49, 7-22. W obu przypadkach chodzi o wyrocznie przeciw Edomowi, które posługują się identycznymi wyrażeniami. Mając na uwadze, że prorok Jeremiasz żył przed Abdiaszem, można założyć, że ten drugi skopiował mowę z pierwszego. Ale sprawa nie jest taka jasna, ponieważ Jr 49, 7-22 w aktualnej redakcji nie wydaje się dziełem tego wielkiego proroka. W rezultacie znajdujemy się w obliczu różnego rodzaju opinii: jedni uważają tekst Ksiegi Abdiasza za oryginalny, inni sądzą, że tekst Księgi Jeremiasza jest oryginalny, jeszcze inni uważają, że obydwaj prorocy zależą od wcześniejszej wyroczni przeciw Edomowi ${ }^{32}$.

Argumenty poszczególnych grup są tak silne, że trudno o kategoryczne rozwiązanie. Innym problemem księgi jest jej podział i data kompozycji. Rzeczą ewidentną w Księdze Abdiasza jest obecność wielu wyroczni. Stąd niektórzy autorzy sądzą że jest to zbiór fragmentów poetyckich pochodzących z różnych okresów. W ten sposób dzielą całość na kilka wyroczni ${ }^{33}$. Wydaje się jednak, że najlepiej jest przyjąć jedność całego pisma. Fragmenty Księgi Abdiasza wiążą się logicznie i stanowią zwartą całość, w której osiemnaście pierwszych wierszy jest tekstem poetyckim, a zakończenie ma charakter prozatorski. W Księdze Abdiasza można wyróżnić dwie główne wyrocznie powstałe w okresie niewoli babilońskiej: 14. 15 i 15a. 16-18. Wyrocznia pierwsza mówi o aktualnej sytuacji historycznej i o sądzie nad Edomem, a druga rozwija temat przyszłości i chwały Izraela. Sąd nad narodami nabiera charakteru eschatologiczno-apokaliptycznego i zostanie dokonany przez zjednoczony Lud Wybrany. W następnej kolejności mamy dodatek w prozie (ww. 19-20), który rozwija ideę zapowiedzianą w wierszu 17: ,[...] dom Jakuba posiądzie tych, którzy go złupili”. Wygnańcy wrócą do swego kraju i jako zwycięzcy wkroczą na Syjon, po czym nastanie królestwo Jahwe. Podzielone są również opinie co do czasu powstania księgi ${ }^{34}$. Prawdopodobnie nawiązuje ona do wypadków z roku 586 roku przed Chrystusem, kiedy Edomici przyłączyli się do Babilończyków atakujących Jerozolimę.

${ }^{32}$ Por. T. Matras, dz. cyt., s. 321-341.

${ }^{33}$ Por. M. Bič, Zur Problematik des Buches Obadjah, „Vetus Testamentum” 3 (1953), s. $11-25$.

${ }^{34}$ Por. M. Gołębiewski, Prorocy mniejsi, w: L. R. Stachowiak (red.), Wstęp do Starego Testamentu, Poznań 1990, s. 324. 
Edomici do Izraelitów odnosili się zawsze wrogo, choć jako potomków Ezawa łączyły ich z Izraelitami więzy pokrewieństwa. Abdiasz zarzucał im zwłaszcza nieprzyjazny stosunek do Jerozolimy w czasie jej upadku i zniszczenia. Prorok, wspominając o tym tragicznym fakcie historycznym, gromił Edomitów za pychę (w. 2-9), za ich złośliwą radość z nieszczęścia, jakie spadło na Izraelitów (w. 10-15) ${ }^{35}$. Może to wskazywać, że Abdiasz prorokował już po upadku Judy i Jerozolimy i po uprowadzeniu Żydów do niewoli babilońskiej, sam będąc przypuszczalnie jednym z jeńców. Dlatego też tę księgę poświęconą Edomowi umieściliśmy w okresie spustoszenia Jerozolimy przez Babilończyków. Jednak wśród uczonych przeważa dzisiaj zdanie, że proroctwo zostało napisane dużo wcześniej. Jakkolwiekby nie było, Abdiasz w ostatniej części swego proroctwa mówi także o czasach ostatecznych, czasach restytucji. Nastapi odnowienie losu - zwyciężeni zostaną wybawieni; wtedy wstąpią na górę Syjon, by sprawować surowy sąd nad krainą Ezawa, a królowanie należeć będzie do Jahwe (w. 21).

Innym prorokiem z okresu wygnania był Ezechiel. W swojej wyroczni (por. Ez 25, 12-14) mówił o Edomie jako przedstawicielu obcych narodów. Wspomniane narody to: Ammon, Moab, Edom, Filistea, Tyr, Sydon i Egipt. W odróżnieniu od tekstów, które zostały wcześniej przywołane, tutaj Edom został potępiony wprost za swoją wrogość wobec Królestwa Południowego. Wyrocznia prezentuje mowę Jahwe, który zapowiada, że ukarze Edom za jego mściwość wobec Judy, co bez wątpienia odnosi się do rebelii z czasów inwazji babilońskiej. Podobny motyw można znaleźć tylko raz - w Księdze Abdiasza (por. Ab 18), gdzie jest zapowiedziane, że „dom Jakuba stanie się ogniem” a „dom Józefa - płomieniem”, a sam „dom Ezawa - słomą”, która będzie spalona tak, że nic nie pozostanie. Są to jedyne dwa teksty w Starym Testamencie, w których Izrael staje się narzędziem w rękach Jahwe dla ukarania Edomu ${ }^{36}$. Podobne myśli możemy odnaleźć w Ez 35. Dlatego też wydaje się, że jest pewna zależność pomiędzy tymi dwoma księgami. To dlatego zostały one razem zaprezentowane w okresie wygnania ${ }^{37}$. Fragment Ez 25, 12-14 wyróżnia się jednak tym, że Izrael ma stać się narzędziem kary i zemsty zesłanej przez Jahwe na Edom. Relacje i podobieństwa między tymi wyroczniami wskazują raczej na to, że Edom nie odgrywa jakiejś niezwykłej roli w kolekcji mów Ezechiela przeciwko obcym narodom. Księga Ezechiela ma swoją wyjątkową pozycję wśród pozostałych ksiąg Pisma Świętego. Wynika to stąd, że daje ona teologiczne rozwiązania problemów w bardzo trudnej sytuacji Ludu Wybranego ${ }^{38}$.

Wina Edomu i potępienie go przedstawiono jako część serii wyroków, które ma podzielić z pozostałymi narodami. Wszystkie grzechy idolatrii wyrażone są

\footnotetext{
${ }^{35}$ Por. M. Bič, dz. cyt., s. 22.

${ }^{36}$ Por. M. Szmajdziński, „Ogień pożerajacy” ('ēš + 'ākal) w Zbiorze Dwunastu Proroków, Częstochowa 2008, s. 207-213.

${ }^{37}$ Por. M. Bič, dz. cyt., s. 22.

${ }^{38}$ Por. J. Homerski, Wódz duchowy narodu wybranego na wygnaniu, „Ruch Biblijny i Liturgiczny" 22 (1969), s. 57-74.
} 
tutaj przez proroka zwrotem 'āśāh tô ‘ēbôt - „,czynić obrzydliwości”. Werset Ez 32, 29 jest częścią ironicznego lamentu proroka nad faraonem, który ma zejść do podziemia (por. Ez 32, 17-32). Władca Egiptu wraz ze swoim wojskiem będzie spoczywał w Szeolu. W ten sposób połączy się z Asyrią, Elamem, Meszkiem, Tubalem, Edomem oraz władcami północy i Sydończykami. Nie pojawia się tu żadne oskarżenie wobec Edomu. Zostało tylko stwierdzone, że naród ten, jego królowie i książęta zostali połączeni z tymi, którzy zginęli od miecza, a teraz leżą pośród nieobrzezanych i przy tych, którzy zstapili do Szeolu. Kontekst całej wyroczni pozwala na stwierdzenie, że Edom nie odgrywa w tym przypadku prestiżowej reprezentacyjnej roli39.

Te dwa rozdziały z Księgi Ezechiela z okresu wygnaniowego, powiązane ze sobą poprzez ukazanie przeciwieństw, dotyczą dwóch przywołanych symbolicznie gór. Pierwszy rozdział zawiera mowę, która ogłasza sąd przeciwko ,górze Seir" (hebr. har śé 'îr), która jest synonimem Edomu. Drugi natomiast obiecuje odnowienie „górom Izraela” (hebr. hārê jiśrā'éel) ${ }^{40}$.

Prorok wysunął cztery podstawowe zarzuty przeciwko Edomowi:

- utrzymywanie ciagłej wrogości i nienawiści wobec Izraela;

- wydanie Izraela pod miecz i wystawienie go na rozlew krwi;

- pragnienie zawładnięcia ziemią Ludu Wybranego i radowanie się jego niedolą;

- postawa pychy wobec Jahwe.

Taka postawa, z prorockiego punktu widzenia, domaga się Boskiej interwencji w postaci sądu. Na podstawie badanych tekstów z Księgi Ezechiela należy dojść do wniosku, że Ezechiel jest wielkim prorokiem przez swoją tajemniczość i głębię. Prorok ma bardzo rozwiniętą wyobraźnię, lubi wielkie sceny, jego alegorie są piękne i czytelne. Prorok Ezechiel, wypowiadając się o Edomitach podobnie jak jego poprzednicy, śledzi z uwagą zmiany polityczne swojej epoki. Zna on wszystkie rozgrywki polityczne międzynarodowe jak również wewnątrz kraju. Opracowuje swój materiał w dużym stylu, nie lubiąc krótkich wyrażeń: przemienia przedmioty w rzeczywistość o porządku symbolicznym i typologicznym ${ }^{41}$. Stosując tego typu środki literackie, Ezechiel nabiera dystansu do rzeczywistości. Prowadzenie argumentacji jest raczej zimne, brak w niej emocji, jaką widać np. u Jeremiasza. Ezechiel wypowiadając się o narodzie edomickim jest nie tylko prorokiem, ale także teologiem. Narodowi na wygnaniu nie wystarczyły apele i gesty profetyczne; chciał i potrzebował on wyjaśnień. Obecnie przyjmuje się powszechnie autorstwo Ezechiela, przynajmniej w głównych częściach księgi. Prorok spisał mowy przeciw Edomitom, które głosił grupom deportowanych, jedne po ich wygłoszeniu, inne przed nim.

39 Por. tamże, s. 53.

${ }^{40}$ Por. J. Bartlett, The Land of Seir and the Brotherhood of Edom, „Journal of Theological Studies" 20 (1969), s. 20.

${ }^{41}$ Por. J. Homerski, Umiłowany przez Boga pasterz czasów mesjańskich, Lublin 1974, S. $139-150$. 


\section{Okres po niewoli}

W połowie VI wieku przed Chrystusem potęga Babilończyków załamała się. Wkrótce ich miejsce zajęli Persowie. W 539 roku przed Chrystusem władca perski Cyrus wydał dekret zezwalający Izraelitom na powrót do ojczyzny. Część wygnańców wróciła $z$ entuzjazmem do Jerozolimy i przystapiła do odbudowy miasta i świątyni. Wielu innych pozostało, gdyż przywykli do życia na obczyźnie, gdzie niejednokrotnie wiodło im się lepiej niż w ziemi ojców. Odbudowanie świątyni (515 rok przed Chrystusem) rozpoczęło tak zwany okres Drugiej Świątyni. Głównym ośrodkiem odradzania się życia religijnego i politycznego stała się Jerozolima i przyległa do niej Judea. Kształt religijności zwanej judaizmem (religią żydowską) określili zwłaszcza dwaj wielcy reformatorzy, Ezdrasz i Nehemiasz, działający w drugiej połowie V wieku przed Chrystusem. Pierwszy podjął reformy religijne zakrojone na szeroką skalę, drugi zajął się konsolidacją polityczną rodaków ${ }^{42}$. Swobodne poczynania obydwu były możliwe, gdyż hegemonia perska miała charakter bardziej pokojowej infiltracji i penetracji aniżeli przymusowych deportacji czy podboju militarnego. Narody i ludy Bliskiego Wschodu, umęczone brutalnością i bezwzględnym wyzyskiem ze strony Asyryjczyków i Babilończyków, z ulgą przyjęły tę zmianę ${ }^{43}$.

Po powrocie z niewoli prorocy (Joel, Malachiasz, TritoIzajasz), wypowiadając się o ,synach Ezawa”, tj. Edomitach, podtrzymywali na duchu ludzi odbudowujących świątynię, zapowiadali przyszłą chwałę świątyni i panowanie Mesjasza oraz stosownie do duchowego położenia narodu wzywali do pokuty i nawrócenia nie tylko Izraela, ale i inne narody. Sytuacja i problematyka czasów powygnaniowych dochodzą do głosu w skardze nad zniszczeniami świątyni (por. Iz 64, 9), jak też w nadziei na odbudowę miasta (Iz 61, 4; 60, 10.18). We wszystkich księgach prorockich traktujących o Edomitach, powstałych po niewoli babilońskiej, znajdują się wyraźne zapowiedzi eschatologiczne ${ }^{44}$. Po wtóre: prorocy z okresu powygnaniowego wypowiadający się przeciw Edomowi i innym obcym narodom pokazywali niewolę babilońską w całym jej wymiarze zewnętrznym. Przestrzegali oni zarazem, że grozi im niewola stokroć groźniejsza, którą sami mogą na siebie sprowadzić, mianowicie poprzez przyłączenie się do kultów i obyczajów bałwochwalczych. Wreszcie po trzecie: prorocy wytrwale przypominali, że Bogu bardzo zależy na swoim ludzie i niewątpliwie nie będzie On długo czekał ze swoją wyzwolicielską interwencją ${ }^{45}$.

${ }^{42}$ Por. tenże, Nehemiasz - świecki reformator religijny, „Roczniki Teologiczno-Kanoniczne KUL" 36 (1989), s. 17-28.

${ }_{43}^{43}$ Por. tamże, s. 21.

${ }^{44}$ Por. S. Zedda, L'escatologica biblica, t. 2, Brescia 1975, s. 71-100; W. Zimmerli, Das Wort des götlichen Selbsterweises (Erweiswort) eine prophetische Gattung, Paris 1957, s. 101-110.

${ }^{45}$ Por. H. Wolff, Joel und Amos. Dodekapropheten 2 - Biblischer Kommentar zum Alten Testament, t. 14/2, Neukirchen-Vluyn 1969, s. 89. 
Prorok Joel, który działał także prawdopodobnie w okresie niewoli i po jej zakończeniu, znany nam jest tylko z imienia ${ }^{46}$. Proroctwo Joela dzieli się wyraźnie na dwie części. Pierwsza (rozdziały 1-2) traktuje o wydarzeniach współczesnych prorokowi. Plaga szarańczy nawiedziła kraj i przy trwającej suszy sprowadziła nań klęskę głodu (J1 1, 2-2,11). Rujnująca plaga szarańczy rozumiana jest jako znak nadejścia „,nia Pańskiego”, kiedy to odbędzie się jeszcze straszniejszy sąd Boży. Joel wzywał lud do okazania skruchy i wyglądał czasów pełnych błogosławieństwa. Prorok, mówiąc o obcych narodach, w tym o Edomitach, wzywał do pokuty i do modlitwy (J1 2, 11-17) i zapowiadał, że jeśli nawrócenie będzie szczere, Jahwe ulituje się nad swoim ludem i obdarzy go znowu plonami (J1 2, 18-27) ${ }^{47}$. Druga część (rozdziały 3-4) to zapowiedź czasów ostatecznych, czasów mesjańskich, zesłania ducha Jahwe na wszelkie ciało, na synów i córki, a także na sługi i służebnice. Jest tu także zapowiedź nadejścia dnia Jahwe (rozdział 4), który będzie dla niektórych dniem kary (Jl 4, 1-13), dla wybranych zaś dniem ostatecznego wybawienia i początkiem niekończącego się szczęścia (J1 4, 14-21).

Malachiasz wierzył z kolei, że jedynym sposobem, aby zaznać Bożego błogosławieństwa, było dotrzymanie wierności Jego przykazaniom. Dużo czasu upłynęło zanim wygnańcom, którzy powrócili do Jerozolimy, udało się wrócić do dawnego życia narodowego. Proroctwo Malachiasza (por. Ml 1,2-5) odnoszące się do Edomitów jest wypowiedziane w kontekście sądu Jahwe nad światem. Wstęp Księgi Malachiasza (Ml 1, 1-5) stwierdza wyraźnie, że Jahwe miłuje swój lud mimo jego nie zawsze właściwego postępowania. Dowodem tego są odmienne losy Izraela i Edomu ${ }^{48}$.

\section{Wnioski}

Wyrocznie o Edomie prorocy kierowali bezpośrednio i przede wszystkim do Ludu Wybranego. Z wcześniejszej analizy i chronologicznego ułożenia mów prorockich przeciw Edomitom w czasie wynika, że mają one charakter upomnień religijo-moralnych i pełnią funkcję pedagogiczną w odniesieniu do całej historii Zbawienia ${ }^{49}$.

${ }^{46}$ Trudno jednak ustalić na podstawie Księgi Joela czas działalności proroka. Zdania są pod tym względem tak dalece rozbieżne, że jedni uważają go za najstarszego z proroków i przyjmuja, że żył w IX wieku przed Chrystusem, inni zaś sądzą, że był ostatnim z proroków działających po niewoli babilońskiej, gdzieś około 400 roku. Prawdopodobnie ostateczna redakcja tej księgi pochodzi z okresu powygnaniowego. Por. J. Bartlett, dz. cyt., s. 20.

${ }^{47}$ Por. J. Guillet, Themes of the Bible, Notre Dame 1964, s. 261.

${ }^{48}$ Por. M. Peter, Proroctwo Malachiasza o ofierze czystej $(1,11)$, „Ruch Biblijny i Liturgiczny" 9 (1956), s. 124-138.

${ }^{49}$ Por. M. Peter, Epoka Malachiasza (Szkic historyczny), „Ruch Biblijny i Liturgiczny” 8 (1955), s. 184-194. 
Stosunkowo łatwo można też zauważyć, że w treści owych wyroczni w ciągu wieków następują pewne przesunięcia dotyczące zarówno akcentowanych prawd, jak też z perspektywy czasu, do jakiego odnosi się treść posłannictwa. W pierwszym przypadku wyroczni prorockich odnoszących się do Edomu chodzi o przesunięcie akcentu od prawd natury moralnej w kierunku kultu (Ezechiel), w drugim zaś o przestawienie się ze współczesnej, bliższej lub dalszej rzeczywistości doczesnej (pierwsi prorocy pisarze) w przyszłość eschatologiczną (późniejsi prorocy pisarze z okresu powygnaniowego). Ta powolna ewolucja perspektyw w sposób wyjątkowo jasny zarysowuje się w wyroczniach o Edomie.

Przeprowadzone powyżej zestawienie wyroczni prorockich przeciwko Edomowi ukazuje, jaką rolę odgrywa ten naród w zamiarze zbawczym Boga. Otóż, karanie tego skądinąd ukazywanego jako zawsze grzesznego narodu miało wpłynąc na poprawę zachowania Izraela - Ludu Bożego. Zaproponowane tutaj ujęcie diachroniczne pozwoliło wydobyć rozwój niezwykle bogatej pod tym względem myśli teologicznej Starego Testamentu, a mówiąc inaczej - pozwala wydobyć obraz Boga jako niezwykłego Pedagoga. Początkowe wyrocznie (Amos, ProtoIzajasz, Jeremiasz) zwracają uwagę, że musi przyjść kara za zerwanie przymierza, zawartego zarówno w świeckim, jak i religijnym wymiarze. W dalszej kolejności prorocy (Ezechiel, Abdiasz) zapowiadają odwet za bezpośrednie podniesienie ręki na Lud Boży (ataki wraz z obcym najeźdźca, grabieże, porywanie w niewolę). W tym przypadku narzędziem kary może stać się sam Izrael. W końcu najmłodsze wyrocznie (Tritolzajasz, Joel, Malachiasz) zapowiadają karę w wymiarze eschatologicznym i potwierdzają Boży wybór Izraela. Lud Wybrany, patrząc na ten cały niezwykle wychowawczy sposób karania, miał uświadomić sobie, że jeżeli to samo zło stanie się jego udziałem, to doczeka się jeszcze gorszej kary $\mathrm{z}$ racji swojego wybrania. Dlatego tytułowe wyrażenie instrumentum paedagogicum w pełni odnosi się do Edomu w procesie wychowawczym Boga-Pedagoga.

Przyglądając się treści wyroczni, w których wspominany jest Edom, można wyciagnąc interesujące wnioski odnośnie do współczesnych relacji Żydów z innymi religiami i narodami. Oczywiste są paralele do konfliktu palestyńskiego. Ale Edom, jako bratni naród Ludu Wybranego, może posłużyć jako klucz hermeneutyczny w interpretacji relacji Żydów do chrześcijan. Ten naród w tradycji żydowskiej był symbolem odwiecznego wroga Izraela. W tekstach talmudycznych, będących spuścizną judaizmu rabinicznego, Ezaw-Edom identyfikowany był z Rzymem, który przyjął chrześcijaństwo.

Należy równocześnie zauważyć, że na relacjach Żydów z innymi narodami oraz relacjach chrześcijańsko-żydowskich zaważyło negatywnie błędne rozumienie idei nawrócenia, zacieśnionej do kontekstu etniczno-konfesyjnego. $Z$ perspektywy Nowego Testamentu można powiedzieć, że wspólna historia Izraela i Edomu ukazuje nawrócenie jako coś więcej - jako uznanie swojej grzeszności i przyjęcie oferty zbawienia, ponieważ zarówno grzech, jak i zbawienie nie podlegają determinacji etnicznej. Tę uniwersalistyczną kondycję wszystkich narodów wyraża Paweł Apostoł: „Wszyscy bowiem zgrzeszyli i pozbawieni są chwały Bożej, a dostępu- 
ją usprawiedliwienia darmo, z Jego łaski, przez odkupienie, które jest w Chrystusie Jezusie" (Rz 3, 23-24). Już na podstawie analizowanych tekstów prorockich odnoszących się do Edomitów można dojść do przekonania, że często oprócz obrazu surowego Boga, który napawa lękiem, w literaturze profetycznej znajdują się przedstawienia Boga kochającego miłością najwyższą. Ta myśl prowadzi bezpośrednio do progu Nowego Testamentu, do orędzia Jezusa Chrystusa. Dokument Papieskiej Komisji Biblijnej (Naród żydowski i jego Święte Pisma w Biblii chrześcijańskiej) podejmuje ten temat, omawiając zagadnienie Bożej kary w obydwu Testamentach (nr 52-53). Chrześcijaństwo wydobywa i akcentuje tę prawdę. Podkreśla, że narody pogańskie zostaną włączone do wspólnoty eschatologicznego Ludu Bożego. Bóg może na końcu czasów stworzyć nowe królestwo, odnowić przymierze z wszystkimi narodami, spełnić to, co było już zapowiedziane przez proroka Izajasza: „Wszystkie narody pospieszą ku Górze Syjonu” (Iz 2, 1).

\section{Edom as instrumentum paedagogicum of the Divine Teacher in the Old Testament (Summary)}

The analysis of the prophetical oracles against Edom shows that this nation plays very important role in the God's plan of the salvation. A punishment of the nation, which is always shown as sinful, should have to influence on betterment of behaviour of Israel - the God's people. A diachronic approach (it means the development of prophets' oracles dating from before to after the Babylonian captivity), which is proposed in the article, permits to observe the development unusually rich theological teaching of the Old Testament. The chronological sequence seems almost indispensable as it allows reading the prophets' statements against Edom in the context of the development of a given religious notion. In the other words it shows God as the unusual Teacher. The first oracles (Amos, Proto-Isa, Jer) show that a punishment has to come because of breaking of the covenant, both in secular as and religious meaning. In more far order prophets (Ezek, Obad) announce retaliation for armed riots against God's People (attacks with strange invaders, plunders, kidnapping in captivity). In this case the tool of punishment can be Israel. In the last oracles (Trito-Isa, Joel, Mal) announce an eschatological punishment and they confirm the God's choice of Israel. The Chosen People, showing on this whole unusually educational way of punishing, had to inform themselves, that if they do the same evil they will receive worse punishment. Therefore the title of this article instrumentum paedagogicum fully applies to Edom in educational process of God-Teacher. 